\title{
Örgütsel Dışlanmanın Çalışanlarda Sinizm Gelişimine Etkisi *
}

\section{The Effect of Organizational Ostracism on the Development of Cynicism in Employees}

\author{
Hasan Tezcan Uysal ${ }^{\text {a,*** }}$ \\ ${ }^{a}$ Öğr. Gör., Bülent Ecevit Üniversitesi, Zonguldak Meslek Yüksekokulu, Yönetim ve Organizasyon Bölümü, 67500, Zonguldak/Türkiye. \\ ORCID: 0000-0002-8962-7824
}

\section{MAKALE BILGİSI}

\section{Makale Geçmişi:}

Başvuru tarihi: 26 Nisan 2018

Düzeltme tarihi: 12 Temmuz 2018

Kabul tarihi: 07 Ağustos 2018

\section{Anahtar Kelimeler:}

Örgütsel Dışlanma

Sinizm

Örgüt Atmosferi

\section{A R T I CLE I N F O}

\section{Article history:}

Received April 26, 2018

Received in revised form July 12, 2018

Accepted August 07, 2018

\section{Keywords:}

Organizational Ostracism

Cynicism

Organizational Atmosphere
ÖZ

Bu araştırmanın amacı; çalışanların örgüt atmosferinde algıladı̆̆ düzeyi arasında anlamlı bir ilişki olup olmadığını saptamak, eğer anlamlı bir ilişki var ise örgütsel dışlanmanın sinizm üzerinde etki düzeyini saptamak ve örgütsel dışlanma algısının demografik faktörlere göre farklılık gösterip göstermediğini incelemektir. Bu amaca bağlı olarak, Ankara ve Zonguldak illerinde özel sektörde ve kamu sektöründe çalışan toplam 272 kişiden anket yöntemiyle veri elde edilmiştir. Gerçekleştirilen analizler sonucunda; örgüt atmosferinde algılanan dışlanma ile örgütsel sinizm arasında pozitif yönde anlamlı bir ilişski saptanmış, çalışanların sinizm düzeyindeki değişimin \%32,7'sini örgütsel dışlanma algısındaki değişimin açıkladığı belirlenmiştir. Basit doğrusal regresyon analizi sonucuna göre; örgütsel dışlanmadaki 1 birimlik artışın örgütsel sinizm üzerinde 0.762 birimlik bir artışa neden olduğu saptanmıştır.

\section{A B S T R A C T}

The purpose of this study is to determine whether there is a meaningful relationship between the ostracism that the employees perceive in the organizational atmosphere and the level of cynicism they have developed and if there is a meaningful relationship, to determine the level of influence of organizational ostracism on cynicism and whether the perception of organizational ostracism differs according to the demographic factors. Based on this purpose, data was collected from a total of 272 individuals working in the public and private sector in Ankara and Zonguldak provinces by survey. As a result of the analyses, a significant and positive relationship was found between organizational cynicism and perceived ostracism in the organizational atmosphere and it was determined that $32.7 \%$ of the change in the cynicism level of employees was explained by the change the perception of organizational ostracism. According to simple linear regression analysis results, it was determined that the 1-unit increase in organizational ostracism caused an increase of 0.762 units on organizational cynicism.

\section{Giriş}

Etkinlik ve verimlilik odaklı modern örgütlerde, bu hedeflerin başarılması için örgütü oluşturan tüm parçaların bir bütün olarak ele alınması gerekmektedir. Parasal sermayenin yanında beşeri sermayenin de çok önemli olduğu günümüz yaklaşımında, örgütlerdeki davranış ve tutumların değerlendirilmesi ve örgüt atmosferindeki faktörlerin uyumlu hale getirilmesi önem arz etmektedir. Dolayısıyla, örgütlerde çalışanları doğrudan veya dolaylı yoldan etkileyen unsurların araştırılması gerekmektedir. $\mathrm{Bu}$ unsurlardan birisi de işyerinde dışlanmadır. Literatürde dışlanmanın ortaya çıkmasıyla gelişen etkiler oldukça önemsenmiştir. Bu etkilerin çalışanlar ve örgütler üzerinde olumsuz psikolojik ve pragmatik sonuçlara neden olabileceği ifade edilmiştir (Robinson vd., 2013). Bu iki sonuçta sosyal etkileşim ağlarının kopmasına, temel insan ihtiyaçlarını ve psikolojik sağlığı tehdit ederek çeşitli işle ilgili kaynakların alışverişinin engellenmesine neden olmaktadır (Al-Atwi, 2017). Bu durum çevresinden soyutlanan çalışanda olumsuz tutumları tetiklemektedir. Ayrıca işyerinde dışlanmanın, diğer bireylerle gerçekleşen, tacizci yönetim ve kabalık gibi örgütsel davranışın karanlık tarafını yansıtan kötü psikolojik muamelelerle ilgili (Leung vd., 2011) olmasından dolayı da çalışan psikolojisi üzerinde

\footnotetext{
* Bu çalışma, 09-11 Nisan 2018 tarihlerinde İstanbul'da düzenlenen 1. Uluslararası Eğitim ve Sosyal Bilimlerde Yeni Ufuklar Kongresinde bildiri olarak sunulmuştur.

** Sorumlu yazar/Corresponding author.

e-posta: h.tezcanuysal@hotmail.com
} 
olumsuz düzeyde yoğun bir etkiye sebep olmaktadır. Dışlanma, çalışanların göz ardı edilmesi ve örgütün diğer üyeleri tarafından dişta tutulma sonucunda ortaya çıkmaktadır. $\mathrm{Bu}$ durum, çalışanlarda bilgi paylaşımı yapmanın ve düşüncelerini ifade etmenin hiç bir anlamı olmadığ 1 hissine neden olmakta ve bundan dolayı da dışlanan çalışanlar kendilerini örgüt içerisinde tam olarak ifade edememektedir (Fatima vd., 2017). Örgüt atmosferiyle kopukluk yaşayan çalışanlarda buna bağlı olarak bireylerin aidiyet, kontrol, benlik saygısı ve anlamlı varlığı için bir tehdit oluşmaktadır (Cursan vd., 2017). Literatür incelendiğinde; Ferris vd. (2008) örgütsel dişlanmayı bir kişinin işyerindeki diğer çalışanlar tarafından göz ardı edildiğine veya dişarıda tutulduğuna yönelik algısı, Robinson vd. (2013) bir birey veya grubun sosyal açıdan uygun olduğunda örgütün başka bir üyesi ile girişimde/iletişimde bulunmayı ihmal etmesi, Estévez ve Serlin (2013) örgütün değerlerine, kültürüne, geleneklerine veya yapısına karşı gerçek veya algılanan ihlal, ihmal veya tehdit iddiasıyla bir bireyin yok sayılması, reddedilmesi ve izole edilmesi, Mahfooz vd. (2017) bir kişi iletişim kurmak istediğinde diğer kişinin sessiz kalması, bireyin boş verilmesi, örgüt içi faaliyetlerden soyutlanması ve benzeri davranışlara maruz kalması olarak tanımlamıştır.

İşyerinde dışlanma, örgüt içersinde çalışanlar arasındaki etkileşimini doğrudan etkilemesi nedeniyle ve örgüt içerisindeki sosyalleşmeyi azaltarak çalışanların psikolojik ihtiyaçlarını karşılamasını engellemesi nedeniyle çok önemlidir (Haq, 2014). Bir çalışanın diğer çalışana yönelik olarak bilinçli bir şekilde gerçekleştirdiği dışlanma, işyerinde başkalarını örtük (imalı) veya pasif olarak görmezden gelme amacıyla yapılan kötü muamelelerin bir örneğidir (Khair ve Fatima, 2017). Olumsuz tutumsal etkisinden dolayı işyerinde dişlanma, örgütsel etkinlik açısından zararlı olabilmekte, dışlanmış çalışanlar örgütün veya diğer bireylerin yararlanabileceği vatandaşlık davranışlarını azaltabilmektedir (Wu vd., 2015). İşyerinde dışlanma, kişiye göre değişen anlayış bileşenlerine sahiptir. Dışlanma algısı veya dişlanıldığını hissetme durumu bireylere göre değişebilmektedir (Çelik ve Koşar, 2015). Ancak, her ne kadar gruba dahil edilmeme gibi pek çok durumda dişlanma algısı önemsenmese de bazı bireyler üzerinde duygusal açıdan olumsuz etkiye neden olmasından dolayı örgütler açısından önemli hale gelmektedir (Waldeck vd., 2015). Örgütlerde dişlanma, yöneticiler tarafindan direk olarak yukarıdan aşağıya doğru gerçekleştirilebileceği gibi iş arkadaşları tarafından yatay olarak da gerçekleşebilmektedir (Khair ve Fatima, 2017). Grup çalışmasının yoğun olduğu örgüt yapılarında kişiler arası veya gruplar arası dışlanma davranışı daha yoğun bir şekilde görülebilmektedir. Özellik olarak reddedilmeden farklılık gösteren dişlanma, pasif, dolaylı ve örtüktür. Reddedilme (rejection) ise aktif, direk ve açıktır (Rajchert vd., 2017). Dolayısıyla örgütsel ilişkilerde dışlanma ve reddedilme farklılık göstermektedir. Reddedilme durumda birey bunu doğrudan ve kısa sürede algılayabilirken dişlanma durumunda ise bireyin bu durumu algılaması zaman almaktadır. Algıladığında ise dışlanma bireyin özsaygısını, ait olma duygusunu ve kontrol duygusunu olumsuz etkiler (Yüksek, 2017). Kişilerarası uygun olmayan bir etkileşim olarak dişlanma, olumsuz kişilerarası deneyimlere ve örgütte kişilerarası ilişkilerde gerginliğe neden olur. Bunun sonucunda da dişlanan bireyler kendisini öfkeli ve aşağılanmış hissederek olumsuz davranıșlar geliștirir, bunun sonucunda da dışlanan bireyler örgütlerine zarar verir ve hatta örgütten ayrılabilir (Chughtai, 2008; Liu ve Xia, 2016). Bu açıdan değerlendirildiğinde dışlanma sadece bireylere arası olumsuz bir etkileşim olarak algılanmamalıdır. Örgütsel işleyişte dışlanmış bireylerde örgüte bağlılığın, etkinliğin ve çalışma performansının sorgulanabilir hale gelmesi örgütün amaçları ve hedefleri açısından olumsuz sonuçlara neden olabilmektedir.

\section{Sinizm ve Örgütlerde Sinik Çalışanlar}

Örgütsel davranış alanındaki çalışmalarda en güncel konulardan birisi de sinizmdir. Sinizm, bireylerin olayları kötü bir bakış açısıyla açıklayıp, olumsuz bir yapıya sahip olmaları anlamına gelmekle beraber sinik bireyin kendi menfaatlerine önem verdiği, bu menfaatleri korumak veya arttırmak için başka insanları araç olarak kullandığı belirtilmektedir (Mautner, 1997). Sinizme yönelik olarak literatürde çeşitli tanımlamalar yapılmıştır. Goldner vd. (1977) sinizmi, örgütün eylemlerindeki, kararlarındaki ve yöntemlerindeki iyiliğinin veya samimiyetinin reddedilmesi, Wanous vd. (1994) ise gelecekte düzenlenecek örgütsel değişikliklerin başarıya ulaşamayacağı ve değişikliği gerçekleştiren liderlerin yetersiz olduğu inancı şeklinde tanımlamıştır. Genel anlamda sinizm, bir bireyde doğuştan var olan kişilik özelliği olarak ifade edilmektedir (Ay ve Ünal, 2016). Örgütsel sinizm ise çalışanların örgütün dürüstlükten yoksun olduğuna yönelik inanç sonucunda gelişmektedir (Nafei ve Kaifi, 2013). Dean vd. (1998) genel sinizmden farklı olarak ele aldığı örgütsel sinizmde sinizmin kişilik özeliğinden farklı bir durum olduğunu, deneyim ve zamanla değişeceğini, sadece polislik gibi belirli mesleklerde değil çeşitli meslekler veya örgütlerde de görülebileceğini belirtmiştir. Örgütlerde sinizmin genel sinizmden farklı olarak ele alınmasının temel nedeni, sinizmin çevreyi etkileyici özelliğinin bulunmasıdır. Bu nedenle sinizm literatürde geniş bir edinmiştir. Örgüt içerisinde sinik çalışanların bulunmasının diğer çalışanları da etkileyeceği ve her ne kadar sinikleşmeseler de örgüte karşı tutumlarının kötüleşeceği düşünülmektedir.

Kalağan ve Güzeller (2010) örgütsel sinizmin inanç, duygu ve davranış eğilimlerden oluştuğunu belirtmiştir. Dolayısıyla genel sinizmden farklı olarak örgütsel sinizmin bilişsel, duyuşsal ve davranışsal olmak üzere üç boyutu bulunmaktadır (Dean vd., 1998). Sinik bireyler, çalıştıkları örgütte dürüstlüğün samimiyetin ve adaletin olmadığına ve buna bağlı olarak da örgütün kendisine ihanet ettiğine inanır (Brandes, 1997). Bireylerin bu inancı bilişsel sinizmi ifade etmektedir. Duygusal boyut ise küçümseme, sıkıntı, öfke gibi olumsuz duyguların şiddetli bir şekilde uyarılması sonucu oluşmaktadır (Abraham, 2000). Duyuşsal boyut, sinizmin, bireyin çalıştığ 1 örgüte yönelik küçümseme ve öfke gibi duygularına ilişkin boyuttur (Akçay, 2017). Davranışsal sinizm boyutunda ise duygularla bütünleşen inancın örgüte karşı olumsuz etkileri görülmektedir. Bu boyutta bireylere örgüte doğrudan zarar verebilecek faaliyetler gerçekleştirmektedir. Bu nedenle de sinizmin gelişmeden önce veya en azından davranışsal boyutta sinizm ortaya çıkmadan önce saptanması gerekmektedir.

Literatürde çeşitli araştırmalar ile sinizme neden olan faktörler tanımlanmıştır. Ahmadi ve Jahanbin (2017) bireysel farklılıklar ile olumlu ve olumsuz iş deneyiminin 
sinizm düzeyini etkilediğini belirlemiştir. Bellini vd. (2015) çalışanların dikkatini dağıtan, rahat hissetmelerine neden olan iş çevresinin çalışanlarda sinizm gelişimini etkilediğini belirlemiştir. Pelit ve Ayana (2016) çalışanlarda duygusal zekânın arttırılmasının sinizm gelişimini azalttığını tespit etmiştir. Öztürk vd. (2016) örgütsel adalet algısındaki düşüklüğünün çalışanlarda sinikleşme düzeyini arttırdığını belirlemiştir. Literatürdeki araştırmalarda da görüldüğü gibi sinizme etki eden pek çok faktör bulunmaktadır. Bu faktörlere yönelik örgüt içerisinde önlem alınmadığında örgüt atmosferi içerisinde sinikleşen çalışanlar, örgütlerine karşı utanç, nefret ve hatta örgütte çalışmanın onur kırıcı olduğu hissine kapılmaktadırlar (Shahzad ve Mahmood, 2012). Sinizm bireylerde diğer insanları aldatıcı, ikiyüzlü, sahtekâr, bencil ve önemsemez olarak görme; diğer bireylerin davranışlarını sorgulayarak ilişkilere güvensizlik duyarak tetikte bulunma; diğer bireyleri hasım veya hükmedici olarak görüp bu nedenle sürekli taleplerde bulunup karşılığında dostluk ve yardım algılayamama olarak ortaya çıkmaktadır (Brandes, 1997). Bu hislere sahip bireylerde doğal olarak stres de görülmektedir. Ancak normal stresten farklı olarak yüksek şiddette hissedilen bu stres hali sinik çalışanın kendisine de zarar vermektedir. Psikolojik ve fizyolojik açıdan sinizm; kalp ve damar hastalıklarına neden olarak çalışanların sağlıklı yaşam süresini kısaltabilmektedir (Eaton, 2000). Davranışsal açıdan sinizm; "çalışanların hem hizmet sundukları kişilere hem de çalıştıkları kuruma karşı rahatsızlık duymaksızın mesafeli, umursamaz ve kinayeli tavirlar sergilemesine neden olmaktadır" (Çimen, 2000:6). Örgütsel açıdan ise; sinizmin yoğunlaştı̆̆1 örgüt atmosferinde örgütler parçalanmaya başlamakta ve örgütü tehdit etmektedir (Naus vd., 2007). Sinizmin bu yıkıcı etkisi karşısında örgütlerin ve örgüt yöneticilerinin duyarsız kalması mümkün değildir. Her ne kadar modern yönetim anlayışı hâkim olsa da, hemen hemen her örgütte sinikleşmiş çalışanların olması muhtemeldir (Güzel ve Ayazlar, 2014). Dolayısıyla örgütlerde sinizmin ve sinizme etki eden faktörlerin saptanması ve bu faktörlere yönelik iyileştirilmelerin yapılması önem arz etmektedir. Brown ve Cregan'ın (2008) da ifade ettiği gibi bireyler arasında paylaşılarak geliştiği ifade edilen sinizm, "düşük liderlik potansiyeli, aşırı şüphecilik, yüksek endişe, içedönüklük ve istismarcı bir inanç sistemi ile pozitif bir ilişki içindedir" (Baz vd., 2011:91). Bu ilişki ağında sinizmi kontrol edebilmek için, çalışanları cesaretlendirmek, tehditleri firsata dönüştürmek ve sinik bireyleri ötekileştirmemek gerekmektedir (FitzGerald, 2002).

\section{Yöntem}

\subsection{Araştırmanın Amacı ve Önemi}

Araştırmanın amacı, örgütlerin devamlılığına ve performansına önemli düzeyde etki eden sinizm üzerinde örgütsel dışlanma algısının anlamlı bir etkisi olup olmadığını saptamak ve çalışanlardaki örgütsel dışlanma algısının demografik faktörlere göre farklılık gösterip göstermediği incelemektir. $\mathrm{Bu}$ amaca bağlı olarak; kamu kurumu çalışanlarına ve özel sektörde çalışanlara yönelik bir araştırma uygulanmıştır. Gerçekleştirilen bu araştırma; sinizme etki eden yeni bir örgütsel faktörü literatüre kazandırması açısından ve örgütü doğrudan tehdit eden sinizmin çözümlenerek elimine edilebilmesi için yönetimsel davranışların belirlenmesi açısından önem taşımaktadır.

\subsection{Evren ve Örneklem}

Araştırmanın evreni, tüm çalışanlardan oluşmaktadır. Araştırmanın örneklemi ise Zonguldak ve Ankara ilinde araştırmaya katılan kamu sektörü ve özel sektör çalışanlarından oluşmaktadır. Araştırmada olasılıklı olmayan örnekleme yöntemlerinden gelişigüzel örnekleme ve amaçlı örnekleme yöntemleri kullanılmış olup, bu kapsamda 283 kamu ve özel sektör çalışanından veri sağlanmış ancak hatalı anketler değerlendirmeden çıkartıldıktan sonra örneklem hacmi 272 olarak belirlenmiştir.

Gerçekleştirilen araştırmalarda $n=\left(\mathrm{t}^{2} \mathrm{x} \sigma^{2}\right) / \mathrm{d}^{2}$ formülü kullanılarak evreni temsil edebilecek örneklem hacmine ulaşılabilmektedir (Akgül ve Çevik, 2005). Bu formüle göre, evrenin standart sapması 20, göze alınan sapma miktarı $\mathrm{d} \pm$ $3, \% 95$ güven düzeyinde ve \pm 0.05 'lik sapma aralığında söz konusu araştırmada gerekli örneklem büyüklüğü 171 olarak hesaplanmaktadır. Araştırma kapsamında toplamda 272 örneklem hacmine ulaşılmış olup, bu değer gerekli örneklem büyüklüğü için yeterlidir. Altunışık vd. (2012) de sosyal bilimlerde 30'dan büyük ve 500'den küçük örneklem büyüklüğünün birçok araştırma için yeterli olduğunu ifade etmiştir.

\subsection{Veri Toplama Arac1}

Araştırmada kullanılacak veriler, çalışanlardan yüz yüze anket yöntemi uygulanarak elde edilmiştir. Bu kapsamda, 5'li Likert tipi iki ölçek içeren anket uygulanmıştır. Ölçeklere ilişkin bilgiler şu şekildedir;

Örgütsel Dışlanma Ölçeği: Çalışanların örgüt içerisinde dışlanmışlık düzeyini ölçmek amacıyla Ferris vd. (2008) tarafindan geliştirilen örgütsel dişlanma ölçeği kullanılmıştır. Ölçeğin Türkçeye uyarlaması Keklik vd. (2013) tarafindan yapılmıştır. Toplam 13 maddeden oluşan ölçek içerisinde "Diğer çalışanlar beni dikkate almaz" ve "Diğer çalışanlar ben orada değilmişim gibi davranırlar" gibi 5'li Likert tarzında sorular bulunmaktadır. Ölçeğin Türkçe versiyonunun yer aldığı çalışmada güvenirlik analiz sonuçları yer almamaktadır ancak ölçeği kullanan Kumral (2017) güvenirlik katsayısını 0.95 saptanmıştır.

Örgütsel Sinizm Ölçeği: Çalışanların örgüt kaynaklı sinizim düzeyini belirlemek için Brandes vd. (1999) tarafından kullanılan sinizm ölçeğinden yararlanılmıştır. 5'li Likert tarzında hazırlanmış ölçek; 5 maddelik bilişsel, 6 maddelik duyuşsal ve 3 maddelik davranışsal olmak üzere üç boyuttan ve toplam 14 maddeden oluşmaktadır. Ölçek, yapısı aynı kalacak şekilde Kalağan (2009) tarafından Türkçeye uyarlanmıştır. Ölçek içerisinde "Çalıştığım kurumda, söylenenler ile yapılanların farklı olduğuna inanıyorum" ve "Çalıştığım kurumu düşündükçe gerilim yaşarım" gibi ifadeler bulunmaktadır. Kalağan (2009) ölçekteki boyutların güvenirlik katsayısını en düşük 0.84 saptayarak ölçeğin iç tutarlılığa sahip olduğunu belirtmiştir.

\subsection{Araştırmanın Modeli ve Hipotezleri}


Araştırmada tarama modeli kullanılmıștır. Araştırmanın bağımlı değişkeni örgütsel sinizm, bağımsız değişkeni ise örgütsel dışlanmadır.

Şekil 2. Araştırmanın Kavramsal Modeli

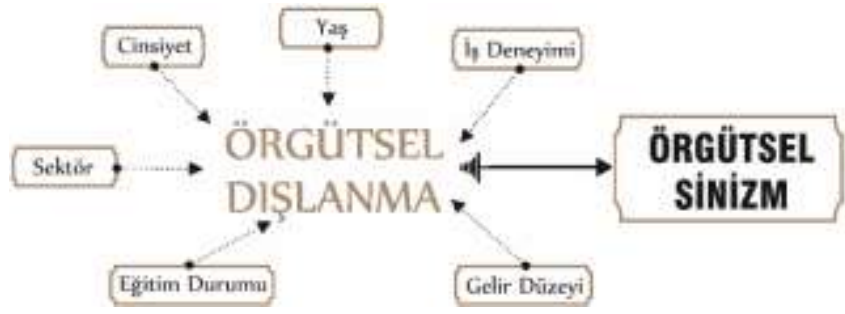

Araştırmanın Hipotezleri;

$H_{\text {la }}$ : Örgütsel dlşlanma ile örgütsel sinizm arasında anlamlı bir ilişki vardır.

$H_{l b:}$ Örgütsel dışlanma arttıkça örgütsel sinizm artar.

$H_{l c}$ : Örgütsel dışlanma yaşa göre anlamlı bir farklılık göstermektedir.

$H_{l d}$ : Örgütsel dişlanma cinsiyete göre anlamlı bir farklılık göstermektedir.

$H_{l e}$ : Örgütsel dışlanma eğitim düzeyine göre anlamlı bir farklılık göstermektedir.

$H_{l f:}$ Örgütsel dişlanma gelir düzeyine göre anlamlı bir farklılık göstermektedir.

$H_{l g}$ : Örgütsel dişlanma iş deneyimi süresine göre anlamlı bir farklllık göstermektedir.

$H_{l k}$ : Örgütsel dışlanma çalışılan sektöre göre anlamlı bir farklılık göstermektedir.

\subsection{Verilerin Analizi}

Araştırmadan elde edilen bulgular SPSS 20.0 (Statistical Package for Social Sciences) programı kullanılarak değerlendirilmiştir. Araştırma ölçeklerinin iç tutarlılığının tespitinde güvenilirlik analizi yapılmıştır. Araştırmada bağımlı ve bağımsız değişkenler arasındaki ilişkinin yönünü ve şiddetini saptamak amaciyla korelasyon analizi, değişkenler arasındaki ilişkiyi incelemek amacıyla basit doğrusal regresyon analizi, farklılıkları saptamak amacıyla da Kruskal-Wallis H Testi ve Mann-Whitney U testi kullanılmıştır.

\section{Bulgular ve Yorumlar}

Örneklemdeki çalışanların demografik sorulara ilişkin cevaplarını içeren frekans değerleri Tablo 1'de yer almaktadır. $\mathrm{Bu}$ bulgulara göre; araştırmaya katılan çalışanların \%54,4'ünün erkek, \%45,6’sının kadın olduğu görülmektedir. Yaş dağılımı incelendiğinde; örneklemin \%69,5'inin 21-40 yaş aralığında olduğu, gelir düzeyleri incelendiğinde \%68,3'ünün 1000TL ile 3000TL arasında, \%1,5'inin ise 1000TL'den daha az bir gelir sahip olduğu belirlenmiştir. Eğitim düzeyleri açısından çoğunluğun \%56,6 ile üniversite mezunlarında oluştuğu görülmektedir. İş deneyimi sürelerine bakıldığında, en baskın grubun 4 yıl ve daha fazla iş deneyimine sahip çalışanlar olduğu, örneklemin sadece \%5,9'unun 1 yıldan daha az iş deneyimine sahip olduğu saptanmıştır. Çalışılan sektör incelendiğinde; örneklemin \%59,6'lık çoğunluğunun özel sektörde çalıştığı belirlenmiştir.

Tablo 1. Veri Sağlayıcıların Temel Bilgileri $(\mathrm{N}=272)$

\begin{tabular}{|c|c|c|}
\hline & Frekans & Yüzde \\
\hline \multicolumn{3}{|c|}{ Cinsiyet } \\
\hline Erkek & 148 & $\% 54,4$ \\
\hline Kadın & 124 & $\% 45,6$ \\
\hline \multicolumn{3}{|c|}{ Yaş } \\
\hline 21' den küçük & 13 & $\% 4,8$ \\
\hline $21-30$ & 72 & $\% 26,5$ \\
\hline $31-40$ & 117 & $\% 43,0$ \\
\hline $41-50$ & 55 & $\% 20,2$ \\
\hline $51-60$ & 14 & $\% 5,1$ \\
\hline 60 'tan büyük & 1 & $\% 0,4$ \\
\hline \multicolumn{3}{|c|}{ Aylık Gelir Düzeyi } \\
\hline 1000 TL' den az & 4 & $\% 1,5$ \\
\hline $1000-2000$ TL aras1 & 95 & $\% 34,9$ \\
\hline 2000-3000 TL aras1 & 111 & $\% 40,8$ \\
\hline $3000-4000$ TL aras1 & 45 & $\% 16,5$ \\
\hline 4000-5000 TL aras1 & 11 & $\% 4,0$ \\
\hline 5000 TL veya daha fazla & 6 & $\% 2,2$ \\
\hline \multicolumn{3}{|c|}{ Eğitim Durumu } \\
\hline İlköğretim & 9 & $\% 3,3$ \\
\hline Lise & 109 & $\% 40,1$ \\
\hline Önlisans & 104 & $\% 38,2$ \\
\hline Lisans & 42 & $\% 15,4$ \\
\hline Yüksek Lisans & 7 & $\% 2,6$ \\
\hline Doktora & 1 & $\% 0,4$ \\
\hline \multicolumn{3}{|c|}{ İş Deneyimi } \\
\hline 1 y1ldan az & 16 & $\% 5,9$ \\
\hline $1-2$ y1l arasi & 42 & $\% 15,4$ \\
\hline $2-3$ y1l aras1 & 42 & $\% 15,4$ \\
\hline $3-4$ y1l arası & 32 & $\% 11,8$ \\
\hline 4 yil veya daha fazla & 140 & $\% 51,5$ \\
\hline \multicolumn{3}{|c|}{ Sektör } \\
\hline Özel & 162 & $\% 59,6$ \\
\hline Kamu & 110 & $\% 40,4$ \\
\hline
\end{tabular}

Tablo 2. Güvenilirlik Analizi

\begin{tabular}{lc}
\hline & Cronbach's Alpha \\
\hline Örgütsel Dişlanma & 0.911 \\
Örgütsel Sinizm & 0.910 \\
\hline
\end{tabular}

Tablo 2'de araştırmada kullanılan ölçeklerin güvenilirliğinin test edilmesinde kullanılan alfa katsayıları (Cronbach's Alpha) yer almaktadır. Gerçekleştirilen güvenilirlik analizleri sonucunda; örgütsel dişlanma ölçeğinin güvenilirlik katsayısı 0.911 ve örgütsel sinizm ölçeğinin güvenilirlik katsayısı 0.910 saptanmıştır. Elde edilen bu değerler, araştırmada kullanılan ölçeklerin çok yüksek iç tutarlılığa sahip olduğunu ifade etmektedir.

Tablo 3. Korelasyon Analizi

\begin{tabular}{llc}
\hline & & Örgütsel Sinizm \\
\hline \multirow{2}{*}{ Örgütsel Dişlanma } & Pearson Correlation & 0.574 \\
& Sig. (2-tailed) & 0.000 \\
\hline
\end{tabular}

Tablo 3'te araştırmanın bağımlı değişkeni ile bağımsız değişkenleri arasındaki korelasyon analizi sonuçları 
görülmektedir. Bu tabloya göre; örgütsel dişlanma ile örgütsel sinizm arasında $(\mathrm{r}=0.574)$ orta seviyede ve pozitif yönde anlamlı bir ilişki saptanmıştır.

Tablo 4. Örgütsel Dışlanma \& Örgütsel Sinizm - ANOVA

\begin{tabular}{lcccc}
\hline \multicolumn{2}{c}{ Sum of Squares } & Mean Square & F & Sig. \\
\cline { 1 - 4 } Regression & 10912.757 & 10912.757 & & \\
Residual & 22246.522 & 82.395 & 132.445 & 0.000 \\
Total & 33159.279 & & & \\
\hline
\end{tabular}

Tablo 4'te örgütsel dişlanma ile örgütsel sinizme yönelik basit doğrusal regresyon analizi görülmektedir. Analiz sonucu incelendiğinde; $\mathrm{F}$ değerinin istatistiksel anlamlılık değerinin 0.05 'ten küçük olmasından dolayı kurulacak regresyon modelinin istatistiksel olarak anlamlılı ifade ettiği saptanmıştır.

Tablo 5. Model Özeti

\begin{tabular}{lccccc}
\hline & $\beta$ & $\mathrm{t}$ & Sig. & $\mathrm{r}^{2}$ & Adjusted $^{2}$ \\
\hline Constant & 15.617 & 8.835 & 0.000 & \multirow{2}{*}{0.329} & \multirow{2}{*}{0.327} \\
Örgütsel D1şlanma & 0.762 & 11.508 & 0.000 & & \\
\hline
\end{tabular}

Tablo 5'te oluşturulan model özeti ifade edilmektedir. Gerçekleştirilen analiz sonucuna göre; çalışanlarda gelişen sinizmdeki değişimin \%32,7'sini örgütsel dışlanma algılarındaki değişimin açıkladığı saptanmıştır. Buna göre örgütsel sinizmin alabileceği değer eşitlik (1)'de ki şekilde formüle edilebilir;

Örgütsel Sinizm $=15.617+(0.762 x$ Örgütsel Dışlanma $)$

Oluşturulan modele göre; çalışanların örgütsel dışlanma algısındaki 1 birimlik artışın sinik birey olma eğilimi üzerinde 0.762 birimlik bir artışa neden olduğu saptanmıştır.

Tablo 6. Örgütsel Dışlanma ve Yaş / Kruskal-Wallis H Testi

\begin{tabular}{cccccc}
\hline Yaş & $\mathrm{N}$ & Mean Rank & Chi-Square & df & Asymp. Sig. \\
\hline$<21$ & 13 & 104.46 & & & \\
$21-30$ & 72 & 154.88 & & & \\
$31-40$ & 117 & 131.50 & & & \\
$41-50$ & 55 & 130.67 & 7.113 & 5 & 0.212 \\
$51-60$ & 14 & 139.04 & & & \\
$>60$ & 1 & 100.50 & & & \\
\hline
\end{tabular}

Tablo 6'da örgütsel dışlanma ile çalışanların yaşı arasındaki ilişki araştırılmaktadır. Tabloda yer alan sonuçlar incelendiğinde; Asymp Sig. (Anlamlılık) değerinin 0.05'ten büyük olduğu görülmektedir. Buna göre; örgütsel dışlanma algısının çalışanların yaşına göre anlamlı bir farklılık göstermediği belirlenmiştir.

Tablo 7. Örgütsel Dışlanma ve Cinsiyet / Mann-Whitney U Testi

\begin{tabular}{ccccccc}
\hline C & N & Mean & $\begin{array}{c}\text { Sum of } \\
\text { Ranks }\end{array}$ & $\begin{array}{c}\text { Mann- } \\
\text { Whitney U }\end{array}$ & Z & Asymp. Sig. \\
\hline$E$ & 148 & 127.24 & 18831.00 & 7805.000 & -2.126 & 0.033 \\
$K$ & 124 & 147.56 & 18297.00 & & & \\
\hline
\end{tabular}

Tablo 7'de çalışanların cinsiyetleri ile örgütsel dışlanma algısı arasındaki ilişki araştırılmaktadır. Asymp. Sig. (Anlamlılık) satırındaki değer incelendiğinde bu değerin 0.05’ten küçük olduğu görülmektedir. Buna göre; örgütsel dışlanma algısının çalışanların cinsiyetine göre anlamlı bir farklılık gösterdiği, kadın çalışanlarda örgütsel dışlanmanın erkek çalışanlara göre daha yoğun algılandığı saptanmıştır.

Tablo 8. Örgütsel Dışlanma ve Eğitim Durumu / Kruskal-Wallis H Testi

\begin{tabular}{lccccc}
\hline Eğitim Durumu & N & $\begin{array}{c}\text { Mean } \\
\text { Rank }\end{array}$ & $\begin{array}{c}\text { Chi- } \\
\text { Square }\end{array}$ & df & $\begin{array}{c}\text { Asymp. } \\
\text { Sig. }\end{array}$ \\
\hline İlköğretim & 9 & 190.33 & & & \\
Lise & 109 & 135.04 & & & \\
Önlisans & 104 & 129.75 & & & \\
Lisans & 42 & 149.06 & 8.826 & 5 & 0.116 \\
Yüksek Lisans & 7 & 133.43 & & & \\
Doktora & 1 & 7.50 & & & \\
\hline
\end{tabular}

Tablo 8'de çalışanların eğitim durumu ile örgütsel dışlanma arasındaki ilişki araştırılmaktadır. Tabloda yer alan sonuçlar incelendiğinde, Asymp Sig. (Anlamlılık) değerinin 0.05'ten büyük olduğu görülmektedir. Buna göre; örgütsel dışlanma algısının çalışanların eğitim durumuna göre anlamlı bir farklılık göstermediği belirlenmiştir.

Tablo 9. Örgütsel Dışlanma ve Aylık Gelir / Kruskal-Wallis H Testi

\begin{tabular}{cccccc}
\hline Aylık Gelir Düzeyi & N & Mean Rank & Chi-Square df & $\begin{array}{c}\text { Asymp. } \\
\text { Sig. }\end{array}$ \\
\hline$<1000 \mathrm{TL}$ & 4 & 152.25 & & & \\
$1001-2000 \mathrm{TL}$ & 95 & 142.07 & & & \\
$2001-3000 \mathrm{TL}$ & 111 & 131.42 & & & \\
$3001-4000 \mathrm{TL}$ & 45 & 131.53 & & & 0.451 \\
$4001-5000 \mathrm{TL}$ & 11 & 172.59 & & & \\
5001 TL veya + & 6 & 102.75 & & & \\
\hline
\end{tabular}

Tablo 9'da çalışanların aylık gelir düzeyi ile örgütsel dışlanma arasındaki ilişki araştırılmaktadır. Tabloda yer alan sonuçlar incelendiğinde; Asymp Sig. (Anlamlılık) değerinin 0.05 'ten büyük olduğu, dolayısıyla da örgütsel dışlanma algısının çalışanların gelir düzeyine göre anlamlı bir farklılık göstermediği tespit edilmiştir.

Tablo 10. Örgütsel Dışlanma ve İş Deneyimi / Kruskal-Wallis H Testi

\begin{tabular}{cccccc}
\hline İş Deneyimi & $\mathrm{N}$ & Mean Rank & Chi-Square & df & Asymp. Sig. \\
\hline$<1$ & 16 & 156.00 & & & \\
1-2 y1l & 42 & 151.46 & & & \\
$2-3$ y1l & 42 & 146.12 & 8.271 & 4 & 0.082 \\
3-4 y1l & 32 & 151.84 & & & \\
4 y1l ve + & 140 & 123.39 & & & \\
\hline
\end{tabular}

Tablo 10 'da iş deneyimi süresi ile örgütsel dişlanma arasındaki ilişki araştırılmaktadır. Tablodaki değerler incelendiğinde, Asymp Sig. (Anlamlılık) değerinin 0.05 'ten büyük olduğu görülmektedir. Buna göre, çalışanların örgütsel dışlanma algısının iş deneyimi süresine göre anlamlı bir farklılık göstermediği saptanmıştır. 
Tablo 11. Örgütsel Dışlanma ve İş Deneyimi / Kruskal-Wallis H Testi

\begin{tabular}{lcccccc}
\hline Sektör & N & Mean & $\begin{array}{c}\text { Sum of } \\
\text { Ranks }\end{array}$ & $\begin{array}{c}\text { Mann- } \\
\text { Whitney U }\end{array}$ & Z & $\begin{array}{c}\text { Asymp. } \\
\text { Sig. }\end{array}$ \\
\hline Özel & 162 & 137.52 & 22279.0 & 8744.000 & -0.261 & 0.794 \\
Kamu & 110 & 134.99 & 14849.0 & & & \\
\hline
\end{tabular}

Tablo 11'de örgütsel dışlanma ile işgörenlerin çalıştığ sektör arasındaki ilişki araştırılmaktadır. Asymp. Sig. (Anlamlılık) satırındaki değer incelendiğinde bu değerin 0.05 'ten büyük olduğu görülmektedir. Buna göre; çalışanların örgütsel dışlanma algısının çalıştıkları sektöre göre anlamlı bir farklılık göstermediği saptanmıştır.

Gerçekleştirilen analizler sonucunda oluşturulan hipotezlere yönelik test matrisi Tablo 12'de ifade edilmiştir.

Tablo 12. Araştırma Hipotezlerinin Test Matrisi

\begin{tabular}{ccc|ccc}
\hline $\mathrm{H}$ & Sonuç & $\mathrm{p}$ & $\mathrm{p}$ & Sonuç & $\mathrm{H}$ \\
\hline $\mathrm{H}_{1 \mathrm{a}}$ & Kabul Edildi & 0.000 & 0.116 & Reddedildi & $\mathrm{H}_{1 \mathrm{e}}$ \\
$\mathrm{H}_{1 \mathrm{~b}}$ & Kabul Edildi & 0.000 & 0.451 & Reddedildi & $\mathrm{H}_{1 \mathrm{f}}$ \\
$\mathrm{H}_{1 \mathrm{c}}$ & Reddedildi & 0.212 & 0.082 & Reddedildi & $\mathrm{H}_{1 \mathrm{~g}}$ \\
$\mathrm{H}_{1 \mathrm{~d}}$ & Kabul Edildi & 0.033 & 0.794 & Reddedildi & $\mathrm{H}_{1 \mathrm{k}}$ \\
\hline
\end{tabular}

\section{Sonuç ve Öneriler}

Gerçekleştirilen çalışma ile örgütsel davranış alanında önemli bir tutum olan sinizm üzerinde çalışanların algıladığg örgütsel dışlanmanın etkisinin olup olmadığı incelenmiştir. Bunun için araştırma kapsamında 8 hipotez öne sürülmüş ve bu hipotezlerin sinanması için 272 kamu ve özel sektör çalışanından anket yöntemiyle veri elde edilmiştir. Elde edilen analizler sonucunda; algılanan örgütsel dişlanma ile örgütsel sinizm arasında pozitif yönde anlamlı bir ilişki saptanmış, çalışanların sinik düzeyindeki değişimin $\% 32,7$ sini örgütsel dişlanmadaki değişimin açıladığı belirlenmiş, regresyon analizi sonucunda; örgütsel dişlanma algısındaki 1 birimlik artışın örgütsel sinizm üzerinde 0.762 birimlik bir artışa neden olduğu saptanmıştır. Farklılık analizleri sonucunda ise; algılanan örgütsel dışlanmanın cinsiyete göre anlamlı bir farklılık gösterdiği, kadın çalışanların örgüt içerisinde dışlanma algısının daha yüksek olduğu belirlenmiştir. Test matrisi incelendiğinde, araştırma kapsamında öne sürülen 3 hipotezin kabul edildiği, 5 hipotezin ise reddedildiği görülmektedir. Buna göre; örgütsel dışlanma, örgütlerde çalışanların sinik olma sürecine önemli düzeyde etki eden yeni bir faktör olarak literatüre kazandırılmıştır.

İşyerinde dışlanma, kişilerarası olumsuz bir deneyim olmasından dolayı, dışlanmış bir çalışan bunu kötülük olarak algılamakta, bu durum da kişiler arası karşıtlığ tetiklemektedir (Zhao vd., 2016). Bu nedenle dişlanma, örgütlerde bireyleri saldırganlığa ve hatta şiddete yatkın hale getirir (Khan vd., 2015). Dışlanmış çalışanlar, kendisini dışlamış olanlardan intikam almanın kabul edilebilir olduğu inancıyla olumsuz karşıtlığı yönlendirebilirler (Zhao vd., 2013). Bu süreçte, psikolojik baskının aksine, dışlanmaya dair belirgin bir işaret olmaması nedeniyle bireyin dışlandığını algılaması ve bu süreci önlemesi zorlaşmaktadır (Ogurlu, 2015). Belirli bir süre sonra algılanabilen dışlanma sonucunda ise dışlanan bireyin, dışlanmasına neden olan gelişmeleri çözümlemesi ve ortadan kaldırması imkânsız hale gelmekte bu da çalışma psikolojisinde hasara sebep olmaktadır. Kronikleşen bu durum ise sinizm gelişimini doğrudan tetiklemekte, önce sinizmin bilişsel boyutunda inançlarını şekillendiren çalışan devamında duygularıyla ifade ettiği inançlarını davranışlara aktararak örgüt atmosferini, örgütün bütünlüğünü ve devamlılığını doğrudan tehdit etmektedir. Dolayısıyla, örgütlerde sinizme neden olabilecek tüm faktörlerin incelenerek literatürde tartışılması gerekmektedir. Bu araştırmada da sinizme neden olabileceği düşünülen ve araştırma sonucunda arasında önemli bir bağ saptanan örgütsel dışlanma kavramı incelenmiş. Gerçekleştirilen araştırma sonucunda; örgüt atmosferinde sinizme doğrudan etki eden dışlanma faaliyetlerinin ve dışlanma algısının minimize edilerek ortadan kaldırılabilmesi için;

(i) İş yeri arkadaşlı̆̆ının gelişmesine yönelik sosyal programların düzenlenmesi,

(ii) Çalışanlara örgüt kültürü benimsetilerek kimlik kazandırılması,

(iii) Örgüt kültürünün dayanışmayı arttırıcı odaklanılması,

(iv) İş arkadaşlığıyla gelişen psikolojik iyi oluş ve yüksek moral çıktısının ifade edilmesi,

(v) Çalışanları örgüte yakınlaştıracak organizasyonların tasarlanmas1,

(vi) Çalışanlara örgütü benimsetecek sembollerin dağıtımı ve kullandırılması,

(vii) Çalışanları kapsayan ortak inanç ve değerlerin sunulmas1,

(viii) Astların problemlerinin üstler tarafından dikkatle ve ciddiyetle dinlenmesi, çözümlenmesi,

(ix) Çalışanın işine, amaçlarına ve görevine yüklediği anlamların derinleştirilerek bütünleşme ihtiyacı hissettirilmesi,

(x) Örgüt içerisinde iletişimin güçlendirilmesi,

(xi) Örgütsel kararlara çalışanların katılımının bir strateji haline getirilmesi,

(xii) Çalışanların hatalarının tolere edilmesi,

(xiii) Hastalık kaynaklı izin isteklerinin olumlu karşılanması,

(xiv) Çalışanlara hastalık, doğum, ölüm gibi özel günlerde destek olunması,

(xv) Örgüt içerisinde iletişim kanallarının daima açık tutulmas1,

(xvi) Mobbing uygulayan çalışanların cezalandırılması, rotasyona tabi tutulması, gerektiğin de örgüt ikliminden izolasyonu,

(xvii) Dışlanması teşvik edecek aşırı otokratik veya pasif liderlik sergilenmemesi,

(xviii) Dışlanmayı kolaylaştırıcı ayrımcılık ve ırkçılık gibi eylemlerin önlenmesi,

(xix) Örgüt içi gruplaşmalara ve çatışmalara gereken ölçüde müdahale edilmesi,

(xx) Şiddetli rekabete ve ayrışmaya neden olan düzenlemelerin ortadan kaldırılması,

(xxi) Gereğinden fazla rekabete / çatışmaya sebep olacak kariyer pozisyonlarının oluşturulmaması,

(xxii) Her türlü kayırmacılıktan (nepotizm, kronizm, favorizm) uzak durulması,

(xxiii) Çalışanlardaki sessizliğin örgütsel, yönetsel veya kişisel nedenlerini ortaya çıkartılması, 
(xxiv) Örgütten ümidini kesmiş çalışanların yeniden örgütün amaçlarıyla bütünleşmesinin sağlanması,

(xxv) Çatışmaya ve dişlanmaya sebep olacak gruplaşmaların engellenmesi,

(xxvi) Örgüt büyüklüğünün en uygun hale getirilmesi,

(xxvii) Örgüt içi adalete özen gösterilmesi,

(xxviii) Statü farklılıklarının mininize edilmesi,

(xxix) Dikey örgüt yapısından yatay örgüt yapısına geçilmesi,

(xxx) Çatışma kaynaklarının yok edilmesi,

(xxxi) Liderin başarıları örgüt çalışanlarıyla birlikte elde ettiğini benimsetmesi,

(xxxii)Çalışanlar ile karşılıklı bağ güdüsü oluşturularak lider-üye etkileşiminin güçlendirilmesi önerilmektedir.

\section{Kaynakça}

Abraham, R. (2000). Organizational Cynicism: Bases and Consequences. Generic, Social, and General, Psychology Monographs, 126(3), 269-292.

Ahmadi, F., \& Jahanbin, M. (2017). Organizational Cynicism, Causes and Consequences in the Ministry of Sport and Youth. Journal of Administrative Management, Education and Training, 13(3), 38-46.

Akçay, V. H. (2017). Örgütlerde İş Rolü Algıları, Sinizm ve Algılanan Performans Arasındaki İlişki. Uluslararası Yönetim İktisat ve Işsletme Dergisi, ICMEB17 Özel Sayıs1, 476-486.

Akgül, A., \& Çevik, O. (2005). Ístatistiksel Analiz Teknikleri. Ankara: Emek Ofset Matbaası.

Al-Atwi, A. A. (2017). Pragmatic Impact of Workplace Ostracism: toward A Theoretical Model. European Journal of Management and Business Economics, 26(1), 35-47.

Altunışık, R., Coşkun, R., Bayraktaroğlu, S., \& Yıldırım, E. (2012). Sosyal Bilimlerde Araştırma Yöntemleri. Sakarya: Sakarya Yayıncılık.

Ay, F. A., \& Ünal, Ö. (2016). The Relationships Between Psychological Contract, Organizational Cynicism and Turnover Intention. Journal of International Health Sciences and Management, 2(2), 102-112.

Baz, M., Kaya, S., \& Savaş, K. (2011). İşveren ve iş gören ilişkileri. Uluslararası Hakemli Akademik Sosyal Bilimler Dergisi, 1(1), 72-95.

Bellini, D., Ramaci, T., \& Bonaiuto, M. (2015). The Restorative Effect of the Environment on Organizational Cynicism and Work Engagement. Journal of Human Resource and Sustainability Studies, 3, 124-135.

Brandes, P. (1997). Organiztional Cynicism: Its Nature, Antecedents, and Consequences. Doctoral Dissertation. USA: Division of Research and Advanced Studies of the University of Cincinnati.

Brandes, P., Dharwadkar, R., \& Dean, J. W. (1999). Does Organizational Cynicism Matter? Employee and Supervisor Perspectives on Work Outcomes. Eastern Academy of Management Proceedings, 150-153.
Brown, M., \& Cregan, C. (2008). Organizational change cynicism: The role of employee involvement. Human Resource, 47(4), 667-686.

Chughtai, A. A. (2008). Impact of Job Involvement on InRole Job Performance and Organizational Citizenship Behaviour. Journal of Behavioral and Applied Management, 9(2), 169-183.

Cursan, A., Pascual, A., \& Félonneau, M. (2017). L'ostracisme. Avancées scientifiques sur la thématique d'une menace quotidienne. Bulletin de psychologie, 70(5), 383-397.

Çelik, C., \& Koşar, A. (2015). Örgüt Kültürü Ve İşyerinde Dışlanma Arasındaki İlişki: Mersin Üniversitesi Çalışanları Üzerinde Bir Uygulama. Ç. Ü. Sosyal Bilimler Enstitüsü Dergisi, 24(2), 47-62.

Çimen, M. (2000). Türk Silahlı Kuvvetleri Să̆llk Personelinin Tükenmişlik, İş doyumu, Kuruma Bağlllık ve İşten Ayrılma Niyetlerine Illişkin Bir Alan Araştırması. Doktora Tezi. Ankara: T.C. Genelkurmay Başkanlığı Gülhane Askeri Tıp Akademisi.

Dean, J. W., Brandes, P., \& Dharwadkar, R. (1998). Organizational Cynicism. Academy of Management Review, 23(2), 341-352.

Eaton, J. A. (2000). A social motivation approach to organizational cynicism. Ontario: York University Toronto.

Estévez, A. M., \& Serlin, J. (2013). Ostracismo organizacional: núcleos conceptuales para la comprensión del fenómeno. Revista Venezolana de Gerencia, 18(64), 567-583.

Fatima, T., Ilyas, M., Rehman, C. A., \& Imran, M. K. (2017). Empirical Investigation of Relationship between Workplace Ostracism and Employee Silence: A Test of Mediating Effects of Self-Esteem and Meaningful Existence in Context of Public Sector Universities in Punjab. Abasyn Journal of Social Sciences, 10(1), 111128.

Ferris, D. L., Brown, D. J., Berry, J. W., \& Lian, H. (2008). The Development and Validation of the Workplace Ostracism Scale. Journal of Applied Psychology, 93, 1348-1366.

FitzGerald, M. R. (2002). Organizational cynicism: Its relationship to perceived organizational injustice and explanatory style. Doctoral Dissertation. University of Cincinnati.

Goldner, F. H., Ritti, R. R., \& Ference, T. P. (1997). The Production of Cynical Knowledge in Organizations. American Sociological Review, 42(4), 539-551.

Güzel, B., \& Ayazlar, G. (2014). Örgütsel Adaletin Örgütsel Sinizm ve İsten Ayrılma Niyetine Etkisi: Otel İsletmeleri Araştırması. KMÜ Sosyal ve Ekonomik Araştırmalar Dergisi, 16(26), 133-142.

Haq, I. U. (2014). Workplace ostracism and job outcomes: Moderating effects of psychological capital. Knowledge and learning international conference, 25-27 June, Portoroz, Slovenia. 
Kalağan, G., \& Güzeller, C.O. (2010). Öğretmenlerin Örgütsel Sinizm Düzeylerinin İncelenmesi. Pamukkale Üniversitesi Eğitim Fakültesi Dergisi, 27, 83-97.

Keklik, B., Saygın, T., \& Kara, N. O. (2013). Akademik Camianın Çirkin Ördek Yavruları ÖYPlilerde Örgütsel Dışlanma (Ostracism) Kavramının İncelenmesi. 1. Örgütsel Davranış Kongresi, Sakarya: Sakarya Üniversitesi, 15-16 Kasım.

Khair, Q., \& Fatima, T. (2007). Interactive Effects of Workplace Ostracism and Belief in Reciprocity on Fear of Negative Evaluation. Pakistan Journal of Commerce and Social Sciences, 11(3), 908-930.

Khan, A. M., Sadiq, M. W., \& Naqvi: M. I. H. (2015). Effect of Ostracism and General Education on Career Development under Mediation of Personality: A Study of Religious Schools in Pakistan. European Online Journal of Natural and Social Sciences, 4(3), 582-595.

Leung, A. S. M., Wu, L. Z., Chen, Y. Y., \& Young, M. N. (2011). The impact of Workplace Ostracism in Service Organizations. International Journal of Hospitality Management, (30), 836-844.

Liu, H., \& Xia, H. (2016). Workplace Ostracism: A Review and Directions for Future Research. Journal of Human Resource and Sustainability Studies, (4), 197-201.

Mahfooz, Z., Arshad, A., Nisar, Q. A., Ikram, M., \& Azeem, M. (2017). Does Workplace Incivility \& Workplace Ostracism influence the Employees' Turnover Intentions? Mediating Role of Burnout and Job Stress \& Moderating Role of psychological Capital. International Journal of Academic Research in Business and Social Sciences, 7(8), 398-413.

Mautner, T. (1997). Dictionary of Philosophy. Penguin Reference Books.

Nafei, W. A., \& Kaifi, B. A. (2013). The Impact of Organizational Cynicism on Organizational Commitment: An Applied Study on Teaching Hospitals in Egypt. European Journal of Business and Management, 5(12), 131-147.

Naus, F., Iterson, A., \& Roe, R. A. (2007). Value incongruence, job autonomy, and organizationbased selfesteem: A self-based perspective on organizational cynicism. European Journal of Work and Organizational Psychology, 16(2), 195-219.

Ogurlu, U. (2015). Ostracism among Gifted Adolescents: A Preliminary Study in Turkey. Educational Process: International Journal, 4(1-2), 18-30.

Öztürk, M., Eryeşil, K., \& Bedük, A. (2016). The Effect of Organizational Justice on Organizational Cynicism and Turnover Intention: A Research on the Banking Sector. International Journal of Academic Research in Business and Social Sciences, 6(12), 18-30.

Pelit, E., \& Ayana, Ç. (2016). The Effect Of Emotional Intelligence On Organizational Cynicism: Research on Hotel Employees. İşletme Araştırmaları Dergisi, 8(2), 45-76.
Rajchert, J., Konopka, K., \& Huesmann, L. R. (2017). It is More than Thought that Counts: the Role of Readiness for Aggression in the Relationship Between Ostracism and Displaced Aggression. Current Psychology, 36(3), 417-427.

Robinson: L., Reilly, J. O' \& Wang, W. (2013). Invisible at Work: An Integrated Model of Workplace Ostracism. Journal of Management, 39(1), 203-231.

Shahzad, A., \& Mahmood, Z. (2012). The Mediating Moderating Model of Organizational Cynicism and Workplace Deviant Behavior: (Evidence from Banking Sector in Pakistan). Middle-East Journal of Scientific Research, 12(5), 580-588.

Waldeck, D., Tyndall, L., \& Chmiel, N. (2015). Resilience to Ostracism: A Qualitative Inquiry. The Qualitative Report, 20(10), 1646-1670.

Wanous, J. P, Reichers, A., \& Austin, J. (1994). Organizational Cynicism: An Initial Study. Academy of Management Best Papers Proceedings, 269-273.

Wu, C., Liu, J., Kwong, K. H., \& Lee, C. (2015). Why and when workplace ostracism inhibits organizational citizenship behaviors: an organizational identification perspective. Journal of Applied Psychology, 101(3), 362378.

Yüksel, M. (2017). Otel İşletmelerinde İşyerinde Dışlama ve Sosyal Zekâ İlişkisi. MANAS Sosyal Araştırmalar Dergisi, 6(3), 115-133.

Zhao, H., Peng, Z., \& Sheard, G. (2013). Workplace ostracism and hospitality employees' counterproductive work behaviors: The joint moderating effects of proactive personality and political skill. International Journal of Hospitality Management, (33), 219-227.

Zhao, H., Xia, Q., He, P., Sheard, G., \& Wan, P. (2016). Workplace ostracism and knowledge hiding in service organizations. International Journal of Hospitality Management, (52), 84-94. 